\title{
Hypoglycaemic effects of the aqueous extract of Newbouldia laevis root in rats
}

\author{
P. O. OKONKWO ${ }^{1 *}$ and Z. S. C. OKOYE ${ }^{2}$ \\ ${ }^{1}$ Department of Chemical Pathology, Federal College of Veterinary and Medical Laboratory Technology, \\ Vom, Nigeria. \\ ${ }^{2}$ Department of Biochemistry, Faculty of Medical Sciences, University of Jos, Jos, Nigeria. \\ Corresponding author, E-mail: Itspatonline@yahoo.com, Phone: 08034508809.
}

\begin{abstract}
The effect of aqueous root extract of Newbouldia laevis (P. Beauv) of the family Bignoniaceae reportedly used in folk medicine to treat diabetes mellitus, on alloxan experimental hyperglycaemia, and normal blood glucose level was determined in adult male rats by glucose Oxidase method. The extract significantly reduced serum glucose levels in both diabetic and normal rats at the two doses administered (500 and $1000 \mathrm{mg} / \mathrm{kg}$ body weight; bucal intubation). In both the normal and diabetic rats, maximal blood glucose lowering effect following extract administration was observed after $4 \mathrm{~h}$ and $6 \mathrm{~h}$, respectively, in rats given 500 and $1000 \mathrm{mg} / \mathrm{kg}$ body weight extract. Phytochemical analysis of the extract reveals a strong presence of alkaloids, flavonoids, and saponins. The observed activity of the extract does not appear at variance with known antidiabetic properties of flavonoids. Hypoglycaemia could be a side effect when extract is applied in folk medical treatment of non-diabetic ailments.

(c) 2009 International Formulae Group. All rights reserved.
\end{abstract}

Keywords: Alloxan, alanine aminotransferase, alkaline phosphatase, aspartate aminotransferase, diabetes, glycaemic response.

\section{INTRODUCTION}

Diabetes mellitus (DM) is a rapidly growing global health problem with far reaching consequences not just for its adverse impact on the health of humanity, but also for the economic burden it places on the health care system (WHO, 1999).

It is a metabolic disorder of multiple aetiology characterised by hyperglycaemia with disturbances of carbohydrate, fat and protein metabolism, resulting from defect in insulin secretion, insulin action or both (WHO, 1999).

In 2000, WHO reported that at least 171 million people worldwide suffer from
DM. Accordingly, projections have been made that the number of diabetics will exceed 350 million by 2030 (Wild et al., 2004).

Diabetes mellitus is associated with long-term complications. The clinical consequences of diabetes can be life threatening and disabling and is currently a chronic disease, without a cure (Vinik et al., 2004).

Though the discovery of insulin and oral hypoglycemic agents has helped in the management of DM, the frequent occurrence of side effects and the toxicities as well as their inability to cure the disease have necessitated the search for plant based 
derivatives for possible use in the treatment of DM. Natural products have been a source of medicinal treatment for many thousands of years and plant based medicine continues to play an important role in the primary health care of $80 \%$ of underdeveloped and developing countries (King et al., 1998).

Newbouldia laevis (P. Beauv) of the family Bignoniaceae is a tropical shrub or small tree. In West Africa, parts of this plant are used in folk medicine to treat diverse ailments (Daziel, 1954; Oliver-Bever, 1960). Extracts of its root, for example, are reportedly used as traditional herbal remedies against dysentery and rheumatic swelling in the Gambia (Daziel, 1954) and roundworm, migraine and earache in Nigeria (OliverBever, 1960). Also in Nigeria, a mixture of ground stem bark and root with oil is used as an ointment on wounds (Daziel, 1954). Amos et al. (2002) reported on the sedative effect of methanolic leaf extract of Newbouldia laevis in mice and rats. Also, Kuete et al. (2007) reported on the antimicrobial activity of methanolic extract and the chemical constituents isolated from Newbouldia laevis. Indigenous folk medicine practitioners of the Jos Plateau, Nigeria, claim that the aqueous extract of the root of N. laevis is also effective against diabetes mellitus. But there appears to be no scientific data in support of the claim. This study was designed to assess the effect of aqueous root extract of Newbouldia laevis on glycemic responses in normal and alloxan induced diabetic rats as to ascertain whether indeed it exhibits hypoglycaemic activity in the mammalian model system.

\section{MATERIALS AND METHODS} Animal

Young adult male Wistar strain albino rats (weighing between 115-120 g) used in the study were purchased from the Animal House Unit, University of Jos and from Small Animal Unit of the Nigerian Institute for Trypanosomiasis Research, Vom. The animals were approved and certified as suitable for experiment by the respective Animal house technical committees. They were maintained on feed pellets purchased from Vital Feeds, Grand Cereals and Oil Mills Ltd., Bukuru, Nigeria and given water ad libitum. The animals were acclimatized for at least 7 days on a regular feed prior to the experiment.

\section{Preparation of $N$. laevis extract}

The aqueous extract was prepared by a laboratory adaptation of the method used by local herbal medicine practitioners. N. laevis root samples were collected in the month of May, 2005 from the premises of the National Veterinary Research Institute, Vom. The plant was identified by Amapitan TA, a taxonomist of Federal college of Forestry, Jos. The roots were dried for two days in an oven at $50{ }^{\circ} \mathrm{C}$ and pounded in a mortar with a pestle. The coarse powder was then transferred to a grinding machine of $1 \mathrm{~mm}$ mesh to grind it to a fine powder. A $20 \mathrm{~g}$ aliquot of the resultant root powder was steeped overnight in $300 \mathrm{ml}$ distilled water.

The mixture was filtered through a Whatman No.1 filter paper. The filtrate was concentrated in vacuo using a rotary film evaporator, and the concentrate was freezedried and stored in the dessicator pending use. The freeze-dried extract was resuspended in distilled water prior to use. The phytochemical composition of the extract was determined qualitatively by the method of Trease and Evans (1989).

\section{Induction of experimental diabetes}

Diabetes was induced with an intraperitoneal dose of alloxan $(100 \mathrm{mg} / \mathrm{kg}$ body weight) following an overnight fast. The dose of alloxan was previously determined in a pilot study. Blood glucose level was determined on days 3, 5 and 7 following the alloxan dose. Blood samples for glucose analysis were collected from the orbital plexus, using non heparinized capillary tubes. Blood glucose concentration was determined by the glucose oxidase method (Valley, 1984). A glucose level above 115 mg/dl (Pileggi and Szusthiewiez, 1974; Peter and Bennett, 1983) was considered a positive 
indication of experimental diabetes and rats with such levels of hyperglycaemia were employed for the root extract study. At the experimental dose, this level of hyperglycaemia was attained by day 7 .

\section{Assay of the effect of root extract on experimental hyperglycaemia}

Eighteen rats were distributed evenly into three groups of six rats each. Rats in each group were individually administered the experimentally determined effective dose of alloxan. Seven days later, rats in groups B and $\mathrm{C}$ were administered a single dose of 500 and $1000 \mathrm{mg} / \mathrm{kg}$ body weight of $N$. laevis extract, respectively, after an overnight fast, by buccal intubation. Rats in group A (control) were given distilled water as drinking water only, after overnight fast. Blood samples were collected from the animals after $0,2,4,6$ and $8 \mathrm{~h}$, respectively, following the administration of the extract and determination of glucose concentration was by glucose oxidase method.

\section{Effect of root extract on blood glucose of normal, untreated rats}

Eighteen rats were distributed evenly into three groups of six rats each. Those in groups $\mathrm{B}$ and $\mathrm{C}$ were administered a single dose of $500 \mathrm{mg}$ and $1000 \mathrm{mg} / \mathrm{kg}$ body weight of the extract, respectively, by buccal intubation after an overnight fast. Those in group A were given distilled water as drinking water only, after an overnight fast. Blood samples were collected for glucose determination as described earlier for the alloxan hyperglycaemia study.

\section{Toxicity risk assay of root extract}

Eighteen rats, distributed evenly into three groups of six rats each, were also used. Prior to treatment, blood samples were collected from all the groups as described earlier, for determination of baseline data. Rats in group A (given distilled water only) served as control while rats in groups B and C were given $500 \mathrm{mg}$ and $1000 \mathrm{mg} / \mathrm{kg}$ body weight of the aqueous root extract, respectively, daily for five days by buccal intubations. Blood samples were collected 24 $\mathrm{h}$ and one week, respectively, following the last dose of the extract from the orbital plexus and serum samples were prepared as described earlier. Serum alanine aminotransferase and aspartate aminotransferase activities were determined by the method of Reitman and Frankel (1957) and alkaline phosphatase activity by the method of King and Armstrong (1954).

\section{Statistical Analysis}

The results were analyzed by one-way ANOVA. Least significant difference (LSD) was used to determine significant results. Differences between groups were considered significant at $\mathrm{p}<0.05$.

\section{RESULTS}

The effects of administration of aqueous root extract of $N$. laevis on blood glucose level in normal rat and in experimental hyperglycaemia are summarized in figures 1 and 2 respectively. As seen from the figures, the aqueous extract significantly $(\mathrm{p}<0.05)$ reduced blood glucose level in both normal and alloxan-induced diabetic rats. Also in either case, the effect of the extract is biphasic and dose related, with the effect on blood glucose level peaking at 4 hours and 6 hours, respectively, in rats administered 500 $\mathrm{mg}$ and $1000 \mathrm{mg}$ extract $/ \mathrm{kg}$ body weight.

The effect of $N$. laevis aqueous root extract on serum liver enzymes of normal albino rats is summarised in table 1. There were no significant changes $(p>0.05)$ in the levels of the liver enzymes on day 1, 6 and 12, following the administration of the 500 and $100 \mathrm{mg} / \mathrm{kg}$ bw of the extract.

\section{DISCUSSION}

The biphasic time course exhibited by $N$ laevis extract would suggest that the active hypoglycaemic principle is rapidly metabolized by rats to an inactive derivative; that the absorbed active principle is rapidly excreted. The peak would then represent the point at which the system mediating the 


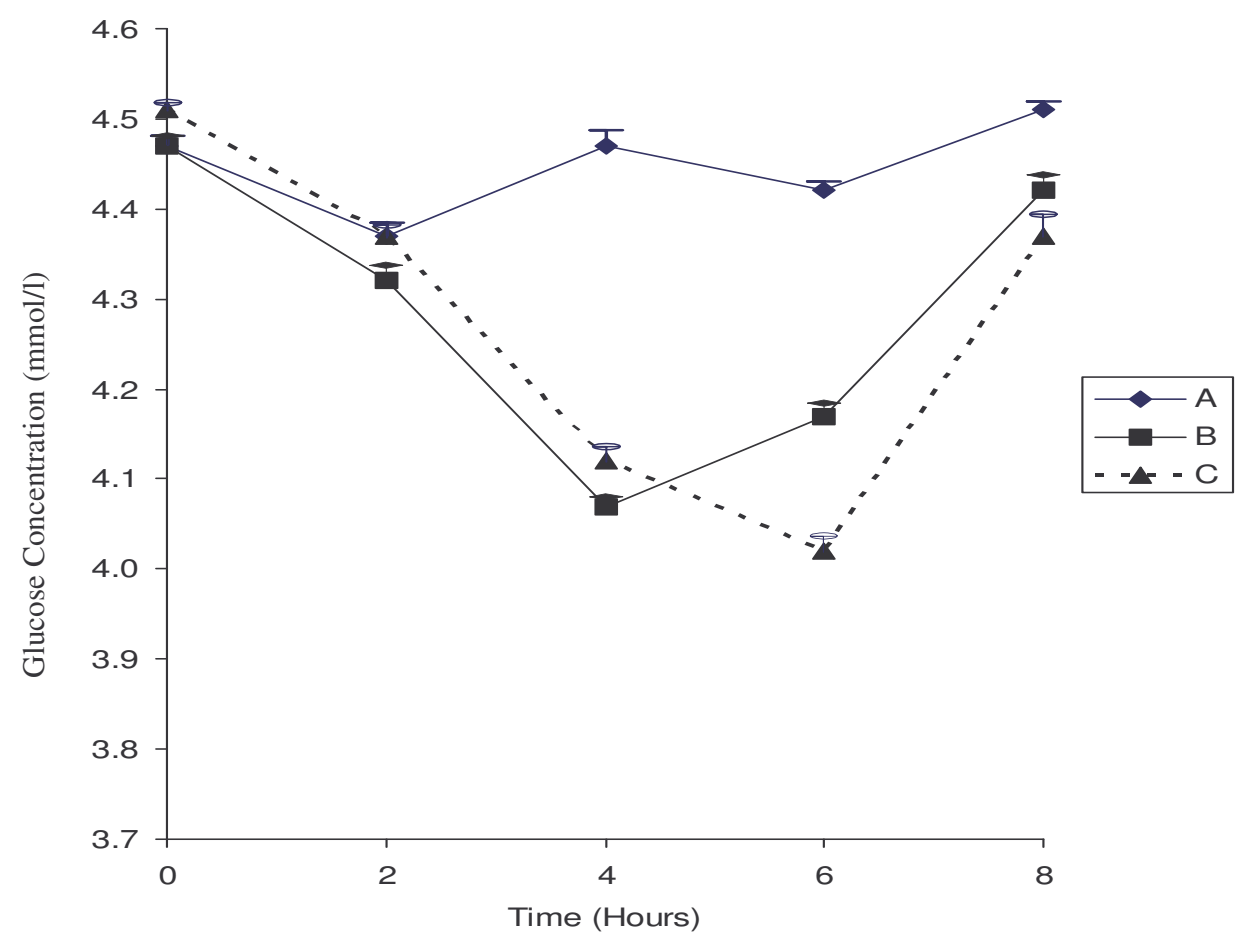

Figure 1: Serum glucose level at different time points in normal rats following administration of aqueous root extract of $N$. laevis. A = Control Group; B = $500 \mathrm{mg} / \mathrm{kg}$ bw; C = $1000 \mathrm{mg} / \mathrm{kg}$ bw.

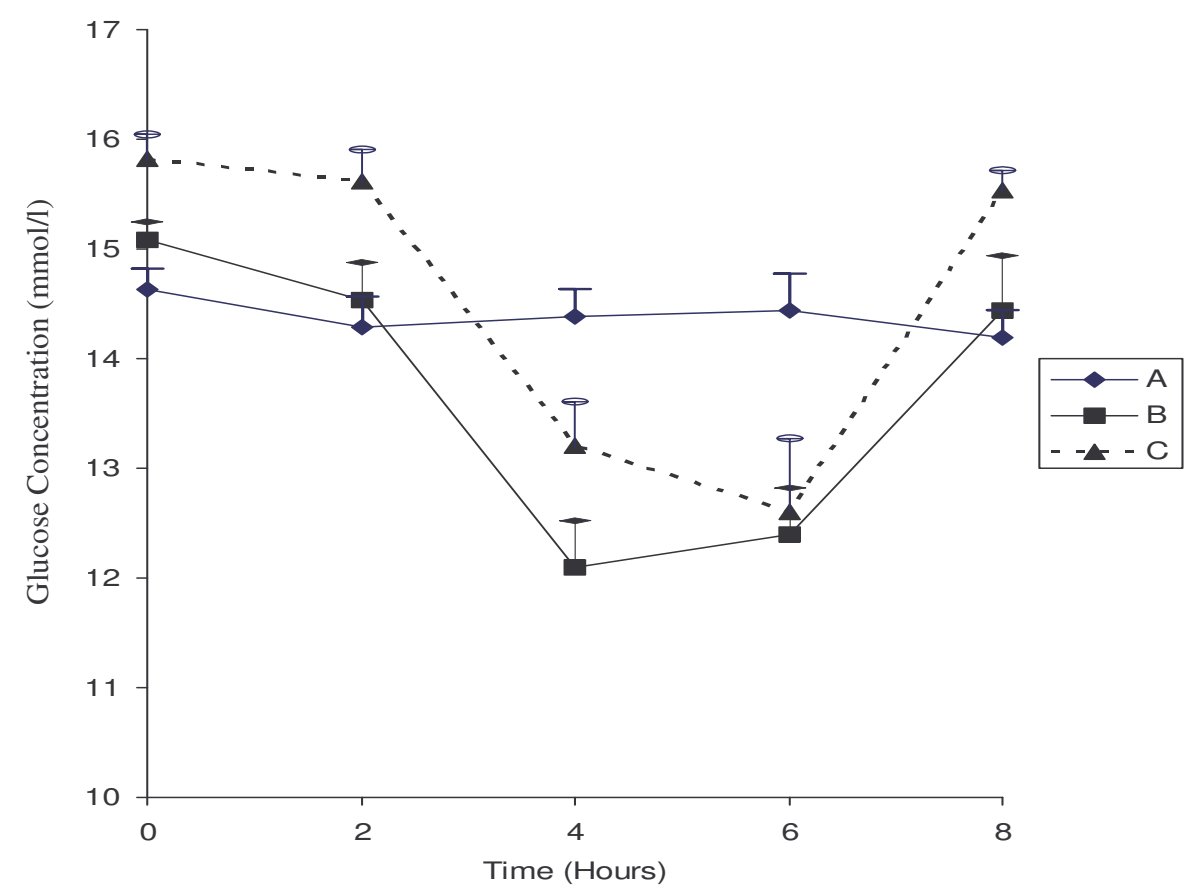

Figure 2: Serum glucose level at different time points in alloxan-induced diabetic rats following administration of aqueous extract of $N$. laevis. A = Control Group; B $=500 \mathrm{mg} / \mathrm{kg}$ bw; $\mathrm{C}=1000 \mathrm{mg} / \mathrm{kg}$ bw. 
P. O. OKONKWO and Z. S. C. OKOYE / Int. J. Biol. Chem. Sci. 3(5): 998-1004, 2009

Table 1: Effect of Newbouldia laevis aqueous root extract on serum alanine aminotransferase, aspartate aminotransferase, and alkaline phosphatase activity of albino rats.

\begin{tabular}{|c|c|c|c|c|c|c|c|c|c|}
\hline \multirow[b]{3}{*}{ Treatment } & \multicolumn{9}{|c|}{ Enzyme Activity (iu/L) } \\
\hline & \multicolumn{3}{|c|}{ ALT } & \multicolumn{3}{|c|}{ AST } & \multicolumn{3}{|c|}{ ALP } \\
\hline & Day 1 & Day 6 & Day 12 & Day 1 & Day 6 & Day 12 & Day 1 & Day 6 & Day 12 \\
\hline $\begin{array}{l}\text { Control } \\
\text { (Distilled Water) }\end{array}$ & $\begin{array}{c}11.75 \\
\pm \\
1.66\end{array}$ & $\begin{array}{c}11.63 \\
\pm \\
0.75\end{array}$ & $\begin{array}{c}11.25 \\
\pm \\
0.87\end{array}$ & $\begin{array}{c}6.25 \\
\pm \\
0.50\end{array}$ & $\begin{array}{c}6.13 \\
\pm \\
0.63\end{array}$ & $\begin{array}{c}6.00 \\
\pm \\
1.41\end{array}$ & $\begin{array}{c}53.56 \\
\pm \\
1.66\end{array}$ & $\begin{array}{c}53.25 \\
\pm \\
1.39\end{array}$ & $\begin{array}{c}53.25 \\
\pm \\
1.39\end{array}$ \\
\hline $\begin{array}{l}\text { Extract } \\
(500 \mathrm{mg} / \mathrm{kg} \mathrm{bw})\end{array}$ & $\begin{array}{c}11.75 \\
\pm \\
1.66\end{array}$ & $\begin{array}{c}12.62 \\
\pm \\
1.70\end{array}$ & $\begin{array}{c}12.13 \\
\pm \\
1.44\end{array}$ & $\begin{array}{c}6.50 \\
\pm \\
0.58\end{array}$ & $\begin{array}{c}6.75 \\
\pm \\
0.5\end{array}$ & $\begin{array}{c}7.75 \\
\pm \\
1.50\end{array}$ & $\begin{array}{c}53.52 \\
\pm \\
1.03\end{array}$ & $\begin{array}{c}53.25 \\
\pm \\
1.39\end{array}$ & $\begin{array}{c}53.52 \\
\pm \\
1.03\end{array}$ \\
\hline $\begin{array}{l}\text { Extract } \\
(1000 \mathrm{mg} / \mathrm{kg} \mathrm{bw})\end{array}$ & $\begin{array}{c}11.38 \\
\pm \\
1.75\end{array}$ & $\begin{array}{c}12.75 \\
\pm \\
2.72\end{array}$ & $\begin{array}{c}12.50 \\
\pm \\
1.00\end{array}$ & $\begin{array}{c}6.38 \\
\pm \\
0.75\end{array}$ & $\begin{array}{c}7.50 \\
\pm \\
1.00\end{array}$ & $\begin{array}{c}7.25 \\
\pm \\
1.26\end{array}$ & $\begin{array}{c}53.52 \\
\pm \\
1.84\end{array}$ & $\begin{array}{c}53.79 \\
\pm \\
1.96\end{array}$ & $\begin{array}{c}53.79 \\
\pm \\
1.96\end{array}$ \\
\hline
\end{tabular}

$\mathrm{ALT}=$ alanine aminotransferase, $\mathrm{AST}=$ aspartate aminotransferase, $\mathrm{ALP}=$ alkaline phosphatase 
hypoglycaemic effect was exposed to the highest concentration of the active principle. The extract induced a significant reduction in blood glucose level at both normal blood glucose concentration and experimental hyperglycaemia. This would suggest that the extract exerts its hypoglycaemic effect irrespective of the blood glucose level.

In particular, the fact that the extract exerted hypoglycaemic action at normal blood glucose appears to indicate that its mode of action may exclude stimulation of insulin. However, since the pathophysiology of diabetes is different, the probable mode of action of $N$. laevis may differ in normal as well as in diabetic rats. Blood glucose levels are controlled by a complex interaction of multiple chemicals and hormones in the body, including the hormone insulin made in the beta cells of the pancreas (Rother, 2007). Under normal circumstances, Insulin production is more or less constant within the beta cells, irrespective of blood glucose level. Its release is primarily triggered by food, chiefly food containing absorbable glucose. Therefore deficiency of insulin or the insensitivity of its receptors plays a central role in all forms of diabetes. In other words, diabetes develops due to a diminished production of insulin or resistance to its effects (WHO, 1999). In addition, the hypoglycaemic action of the extract at normal blood glucose may also suggest that Hypoglycaemia could be a side effect when extract is applied in folk medical treatment of non-diabetic ailments.

The active principle responsible for the hypoglycaemic action of the extract was not determined in the present study. However, the phytochemical screening results suggest a strong presence of alkaloids, flavonoids, and saponins in the extract. Epidemiological studies have associated consumption of flavonoids with reduced risk of adult-onset diabetes mellitus (Knekt et al., 2002). Flavonoids are believed to exert their protective action through several biological mechanisms. For example, it has been shown that isoflavones, a class of flavonoids, display a range of properties which may be of benefit in diabetes, normally as an estrogenic agent, an inhibitor of intestinal glucose uptake and a preventive agent for glucose induced lipid peroxidation (Vedavanam et al., 1999). It is possible that $N$. laevis extract may be acting by one of these mechanisms, given its effect on normal rats.

The $N$. laevis root extract does not appear to have adverse cytotoxic effects on the mammalian tissue at the two experimental doses as determined by serum aminotransferases and alkaline phosphatase activities (Table 1). There were no significant changes in actives compared to the control.

This study has attempted to investigate the effect of the $N$ laevis extract in serum glucose level in order to provide scientific data in an effort to confirm the claim of indigenous folk medicine practitioners that $N$. laevis is effective against diabetes mellitus. This will provide a plus on the existing literature on other medicinal values of the extract (Amos et al, 2002; Kuete et al, 2007).

\section{Conclusion}

Study has shown that $N$ laevis extract exert hypoglycaemic effect on the normal as well as in alloxan-induced diabetic rats and the extract does not appear to have adverse cytotoxic effects on the liver cells at the two experimental doses administered as determined by serum liver enzymes following the toxicity risk assay. The phytochemical screening results suggest a strong presence of alkaloids, flavonoids, and saponins in the extract. However, the probable mode of action and the active principle responsible for the hypoglycaemic action of the extract was not determined in the present study.

A further study may be considered for a long-term study design as against this short term research to further confirm the extract as hypoglycaemic and its mode of action may be studied in a more elaborate platform.

\section{ACKNOWLEDGEMENTS}

The authors are grateful to Federal College of Veterinary and Medical Laboratory Technology, National Veterinary Research 
Institute Vom, for sponsorship of POO's study at University of Jos and to the late Dr LOM for technical assistance.

\section{REFERENCES}

Amos S, Binda L, Vonqtau H, Chindo B, Abbah J. 2002. Sedative effects of the methanolic leaf extract of Newbouldia laevis in mice and rats. Boll Chim farm., 141(6):471-5

Dalziel JM. 1954. The Useful Plants of West Tropical Africa. Crowns Agents for Oversea Government: London; 11651166.

King EJ, Armstrong AR. 1934. Determination of serum alkaline phosphatase activity. In Practical Clinical Biochemistry, Valley H, Gowenlock AH, Bell M (eds). William Heinemann Medical Books Ltd.: London; 1: 897-900.

King H, Aubert RE, Herman WH. 1998. Global burden of diabetes, 1995-2005: prevalence, numerical estimates, and projections. Diabetes Care, 21: 14141431

Knekt P, Kumpulainen J, Jarvinel R, Rissanen H, Heliovaara M, Reunanen A, Hakulinen T Aroma A. 2002. Flavonoids are effective antioxidants and may protect against several chronic diseases. Am. J. Clin. Nutr., 76: $560-568$.

Kuete V, Eyong KO, Folefoc,GN, Beng,VP, Hussain H. 2007. Antimicrobial activity of the methanolic extract and the chemical constituents isolated from Newbouldia laevis. Pharmazie, 62(7): 552-556.

Oliver-Bever B. 1960. Medicinal Plants in Tropical West Africa. Cambridge University Press: Cambridge; 1-20.

Peter H, Bennett MB. 1983. Diabetes Mellitus: Theory and practice. Medical Examination Publishing Co. Inc.: New York; 409-414.
Pileggi VJ, Szusthiewiez CP. 1974. Clinical Chemistry Principles and Techniques (2nd edn). Harper and Row: Maryland; 1265-1326.

Rietman S, Frankel S. 1957. A method of assaying liver enzymes in human serum. Am. J. Clin. Path., 28:56-58.

Rother, KI. 2007. Diabetes TreatmentBridging the Divide. N. Engl. J. Med., 356(15): 1499-1501.

Trease GE, Evans WC. 1989. A Text book of Pharmacognosy (13th edn). Bailliere Tinall Ltd.: London; 546.

Valley H, Gowenlock AH, Bell M. 1984. Practical Clinical Biochemistry. William Heinemann Medical Books Ltd.: London; 1: 385-405.

Vedavanam K, Srijayanta S, Reilly JO, Raman A, Wiseman H. 1999. Antioxidant action and potential antidiabetic properties of an isoflavonoid-containing soyabean phytochemical extract (SPE). Phytotherapy Research, 13: 601-608.

Vinik AI, Fishwick DT, Pittenger G. 2004. Advances in diabetes for the millenium: toward a cure for diabetes. MedGenMed: Medscape general medicine; 6 (3): 12.

Wild S, Roglic G, Green A, Sicree R, King H. 2004. Global prevalence of diabetes: estimates for the year 2000 and projections for 2030. Diabetes Care, 27(5): 1047-1053.

World Health Organization. 1999. Definition, Diagnosis and Classification of Diabetes Mellitus and its Complications. Department of Non-Communicable Disease Surveillance, World Health Organization: Geneva; 1-37. 